\title{
Mangrove carbon sink. Do burrowing crabs contribute to sediment carbon storage? Evidence from a Kenyan mangrove system
}

\author{
Anna Andreetta ${ }^{\mathrm{a}, *}$, Marco Fusi ${ }^{\mathrm{b}, \mathrm{c}}$, Irene Cameldi ${ }^{\mathrm{a}}$, Filippo Cimò ${ }^{\mathrm{d}}$, Stefano Carnicelli ${ }^{\mathrm{a}}$, Stefano Cannicci ${ }^{\mathrm{b}}$ \\ a Department of Earth Sciences, University of Florence, Firenze, Italy \\ ${ }^{\mathrm{b}}$ Department of Biology, University of Florence, Firenze, Italy \\ c University of Study of Milan, DeFENS, 20133 Milan, Italy \\ d Istituto per lo Studio degli Ecosistemi, CNR, Via Madonna del Piano 10, 50019 Sesto Fiorentino, Florence, Italy
}

\section{A R T I C L E I N F O}

\section{Article history:}

Received 17 January 2013

Received in revised form 16 August 2013

Accepted 24 August 2013

Available online 2 September 2013

\section{Keywords:}

Mangrove

Soil

Carbon Stock

Crabs

Carbon Burial

\begin{abstract}
A B S T R A C T
Mangrove ecosystems are acknowledged as a significant carbon reservoir, with a potential key role as carbon sinks. Little however is known on sediment/soil capacity to store organic carbon and the impact of benthic fauna on soil organic carbon (SOC) stock in mangrove C-poor soils. This study aimed to investigate the effects of macrobenthos on SOC storage and dynamic in mangrove forest at Gazi Bay (Kenya). Although the relatively low amount of organic carbon (OC\%) in these soils, they resulted in the presence of large ecosystem carbon stock comparable to other forest ecosystems. SOC at Gazi bay ranged from $3.6 \mathrm{~kg} \mathrm{~m}^{-2}$ in a Desert-like belt to $29.7 \mathrm{~kg} \mathrm{~m}^{-2}$ in the Rhizophora belt considering the depth soil interval from $0 \mathrm{~cm}$ to $80 \mathrm{~cm}$. The high spatial heterogeneity in the distribution and amount of SOC seemed to be explained by different dominant crab species and their impact on the soil environment. A further major determinant was the presence, in the subsoil, of horizons rich in organic matter, whose dating pointed to their formation being associated with sea level rise over the Holocene. Dating and soil morphological characters proved to be an effective support to discuss links between the strategies developed by macrobenthos and soil ecosystem functioning.
\end{abstract}

(c) 2013 Elsevier B.V. All rights reserved.

\section{Introduction}

Over the last decades, there has been a strong interest in understanding how factors, such as vegetation and climate, control organic carbon accumulation in soils and sediments, and whether this process could mitigate $\mathrm{CO}_{2}$ impacts on climate change (Jobbágy and Jackson, 2000).

Mangrove forests are ecosystems thriving in the intertidal belt, on sediments made waterlogged and saline by regular flooding. Mangrove forests cover roughly $137,760 \mathrm{~km}^{2}$ along the coasts of the world (Giri et al., 2011) and accumulate $26.1 \mathrm{Tg}$ of organic carbon annually (Breithaupt et al., 2012). Many authors argue that they rank among the most carbon-rich forest soils in the tropics (Chmura et al., 2003; Donato et al., 2011; Fujimoto et al., 1999; Kristensen et al., 2008; Matsui, 1998).

Kristensen et al. (2008) reviewed data on mangrove sediment carbon incorporation rates. They observed that carbon burial rates estimated using a bottom-up approach (Duarte et al., 2005) referred to sediments showing an average carbon content of $8.5 \%$, while a compilation of carbon content of world mangrove sediments produced a much lower average, close to $2.2 \%$ (Kristensen et al., 2008).

Sedimentation of carbon-rich mud is often assumed as the main process of carbon burial in mangrove forests, and sediment accretion rate is

\footnotetext{
* Corresponding author. Tel.: + 390553288290.

E-mail address: anna.andreetta@unifi.it (A. Andreetta).
}

used as a proxy for overall C sequestration (Chmura et al., 2003). Sediment accretion rate increases from the high to the low intertidal zone (Alongi et al., 2005); intertidal mudflats, often lying seawards to mangrove forests, may actually accumulate more sediment and carbon than the forest themselves (Sanders et al., 2010a,b). A second major allochthonous component is the continuous exchange with the large carbon reservoir of the ocean, as daily tides drive inwelling and outwelling of organic matter (Bouillon et al., 2003; Dittmar et al., 2006).

Several autochthonous components of mangrove carbon cycle remain unaccounted for (see Kristensen et al., 2008 for a review). The main such components are root-to-soil $\mathrm{C}$ transfer and the role of macrobenthos (Cannicci et al., 2008; Kristensen et al., 2008; Nagelkerken et al., 2008).

Sesarmid and ocipodid crabs are the major bioturbating and bioengineering components of the mangrove fauna, through their feeding and digging activities (Cannicci et al., 2008; Kristensen et al., 2008; Lee, 1998). Sesarmids dig burrows down to 2 meter depth and store leaf litter, mangrove propagules and other organic material from different sources (Dahdouh-Guebas et al., 1997; Dye and Lasiak, 1987; Micheli, 1993; Micheli et al., 1991; Robertson and Daniel, 1989; Skov and Hartnoll, 2002; Smith et al., 1991; Sousa and Dangremond, 2011). Their burrows then work as traps, shielding organic materials from flushing by ebb tides (Lee, 2008) and enhancing retention of organic C within the system (Kristensen et al., 2008). These 
leaf-consumers remove, through consumption or burial, between $28 \%$ and $79 \%$ of annual leaf-litter fall, according with the characteristics of the considered mangrove (Robertson, 1986, 1991; Robertson and Daniel, 1989; Twilley et al., 1997). Despite their being considered mainly herbivorous, sesarmids can exploit different food sources, as mud, bacteria or dead animals, in order to enrich their diet in nitrogen, as mangroves are nitrogen-poor environments (Skov and Hartnoll, 2002; Thongtham and Kristensen, 2005). Exploiting diversified food sources, they can possibly bury also other kinds of organic material (Sousa and Dangremond, 2011).

Ocipodid crabs are mainly represented, in mangrove systems, by the pantropical genus Uca. Although they often share habitats with sesarmids, they rely on different food sources (Macnae, 1968; Jones, 1984; Dahdouh-Guebas et al. 2002). They are filter feeders (Icely and Jones, 1978; Ribeiro and Iribarne, 2011) that are able to exploit food sources from the sediment, such as bacteria, benthic microalgae and meiofauna (Reinsel, 2004). As filter feeders they feed on the sediment surface, never burying organic material, as common for sesarmids. While filtering, they plough the top sediment layer, inducing oxidation and changes in biogeochemical properties, influencing such phenomena as bacterial and algal eutrophication (Bartolini et al., 2011; Kristensen and Alongi, 2006). Ocipodid burrows are typically less deep than the ones of sesarmids, but they can reach a density of 100 per square metre of forest or sand/mudflat ground (Cannicci et al., 2009; Geist et al., 2012; Hartnoll et al., 2002; Penha-Lopes et al., 2009). Burrows are essential as breeding sites (Mautz et al., 2011; Milner et al., 2010), as shelter during high tide (Booksmythe et al., 2012; Crane, 1975) and for thermoregulation during low tide activity (Edney, 1961), while fiddler crabs behave as central-place foragers (Crane, 1975; Zeil et al., 2006). Through burrow digging and maintenance, ocipodids enhance oxygen flux into the waterlogged sediment, facilitating oxidation and enhancing nutrient availability, sediment bacterial communities (Kristensen and Alongi, 2006) and biogeochemical processes (Holguin et al. 2001; Kristensen et al., 2008). Crabs also transfer biomass to the sediment via their exuviae and faeces, though there is lack of data about this process, as remarked by Alongi (2002, 2009); see also Eong, (1993). These clear differences in feeding and burrowing behaviour of the two burrow-builder crab families likely lead to different effects on sediment properties (Kristensen and Alongi, 2006) and carbon storage. However, to our knowledge, this latter topic has not been yet studied (Lee, 2008) and represents one of the main topics of this paper.

Published data on belowground carbon storage in mangrove ecosystems have recently increased (Donato et al., 2011; Fujimoto et al., 1999; Sanders et al., 2010a,b). Most of these studies show, however, the same sort of bias noted by Kristensen et al. (2008), as they analyse mangroves growing on carbon-rich sediments. Though there is no definite assessment of the relative importance of C-rich and C-poor sediments in world mangrove ecosystems, evidence of mangroves growing on soils with low $\mathrm{C}$ content continuously emerges. In the ecosystem studied by Sanders et al. (2010a,b), the soil C pool amounts to $23.5-24.8 \mathrm{~kg} \mathrm{~m}^{-2}$, much lower than reported by other authors. Recently, both Tue et al. (2011) and Ranjan et al. (2011) report on mangroves growing on sediments with low $\mathrm{C}$ content.

Most data on belowground $C$ storage have been gathered through a "sedimentological" approach, sampling mangrove substrata with piston corers and analysing them by depth slices (Sanders et al., 2010a,b). However, the ability of mangrove sediments to support rooted plants, combined with the identification of numerous surface-related process, such as addition of organic matter, transfer of elements and mineral weathering, allows to consider mangrove substrates as pedogenised sediments (e.g. soils; see Joffe, 1936; Paton et al., 1995; Ferreira et al., 2007a; Soil Survey Staff, 2010). Thus they can be described and sampled by standard pedological procedures, as for examples by opening soil profiles. Soil profiles supply information on such morphological characters as redoximorphic features, shape and size of biological channels, horizon development and organic matter distribution, indicative of surface-related processes and of macrobenthos activity.

The main objective of this cross-disciplinary study was to assess the contribution of key bioturbators to soil organic matter dynamics. For this purpose, specific aims were set as: a) the quantification of soil $\mathrm{C}$ storage in Gazi bay, a mangrove ecosystem forest thriving on C-poor soils; b) the evaluation of crab biomass distribution in the mangrove forest; c) the identification of the contribution of key-bioturbators to carbon storage, by a combined pedological and biological approach.

\section{Material and methods}

\subsection{Study area}

Gazi Bay $\left(4^{\circ} 22^{\prime} \mathrm{S}, 39^{\circ} 30^{\prime} \mathrm{E}\right)$ is a semi-enclosed, shallow bay about $40 \mathrm{~km}$ South of Mombasa in Kwale district, Kenya (Fig. 1). The climate of the Kenyan coast is typically monsoonal, influenced by the moist southeast monsoon from March to September and by the dry northeast monsoon from October to March; rain occurs in March-May and, to a lesser extent, October and November. Total annual precipitation fluctuates between 1000 and $1600 \mathrm{~mm}$, showing a bimodal distribution pattern. Air is hot and humid, with an average temperature of about $28^{\circ} \mathrm{C}$ and little seasonal variation; relative humidity is about $95 \%$, due to the close proximity to the sea (Kitheka, 1996).

A mangrove forest, up to $3.3 \mathrm{~km}$ across and with an area of about $6.61 \mathrm{~km}^{2}$, surrounds the northern shores of the bay (Matthijs et al., 1999). The mangrove forest receives low freshwater and sediment inputs. Tidal amplitude ranges from about $1.4 \mathrm{~m}$ to $4 \mathrm{~m}$ at neap and spring tides, respectively, generating significant flows across the bay. The large Thalassia seagrass beds $\left(7 \mathrm{~km}^{2}\right)$, lying southwards and seawards from the mangroves, likely act as a trap of nutrients (Kitheka, 1996).

\subsection{Sampling}

A transect was established across the intertidal zone; as a strong relationship was found between tidal flooding intervals and vegetation (Fig. 1) four distinct mangrove compartments were defined as stations.

The "Desert-like belt" (DES1 and DES2 representative soil profiles) is only flooded at the highest spring tides, about 5 days per month, and is mostly bare (Fig. 1). The "Avicennia belt" (AV1 and AV2 profiles), bounded by high spring tide and high neap tide levels, is covered by a fairly closed canopy of Avicennia marina forest with a Leaf Area Index (LAI) of 1.18 (Robert et al., 2009; Schmitz et al., 2008). The Upper Eulittoral belt is bounded by high neap tide and average sea levels; Ceriops tagal (CER), is the dominant specie but a pure open forest (LAI 0.23 ) of A. marina is also present (AV3). Although Avicennia forests in both zones are of the basin scrub-type (Middelburg et al., 1996), the Upper eulittoral belt trees are smaller (mean height of $2 \mathrm{~m}$ ) compared to those in the Avicennia belt (Robert et al., 2009; Schmitz et al., 2008). The "Rhizophora belt" (RHI), dominated by Rhizophora mucronata, lies below average sea level and, being daily inundated, has nearly permanently saturated soils.

Sampling took place in October 2009. Triplicate soil profiles were sampled both according to soil genetic horizons, which were distinguished by features dependent on pedogenesis (Soil Survey Staff, 2010), and to fully represent fixed depth intervals, set as $0-10,10-20$, $20-40$ and $40-80 \mathrm{~cm}$. Further samples were collected by auger to check soil spatial variability for each belt. Descriptions of 7 representative soil profiles (DES1, DES2, AV1, AV2, AV3, CER, RHI), are presented. Samples for bulk density (BD) were collected for the fixed depth intervals with a $123.15 \mathrm{~cm}^{3}(\mathrm{~h}=5 \mathrm{~cm}$ and $\mathrm{r}=2.8 \mathrm{~cm})$ steel cylinder.

\subsection{Estimation of crab biomass and matter stored in sesarmid burrows}

For each belt, five $2 \times 2 \mathrm{~m}$ random quadrats were sampled to assess the density of crab populations. Different sampling techniques were 

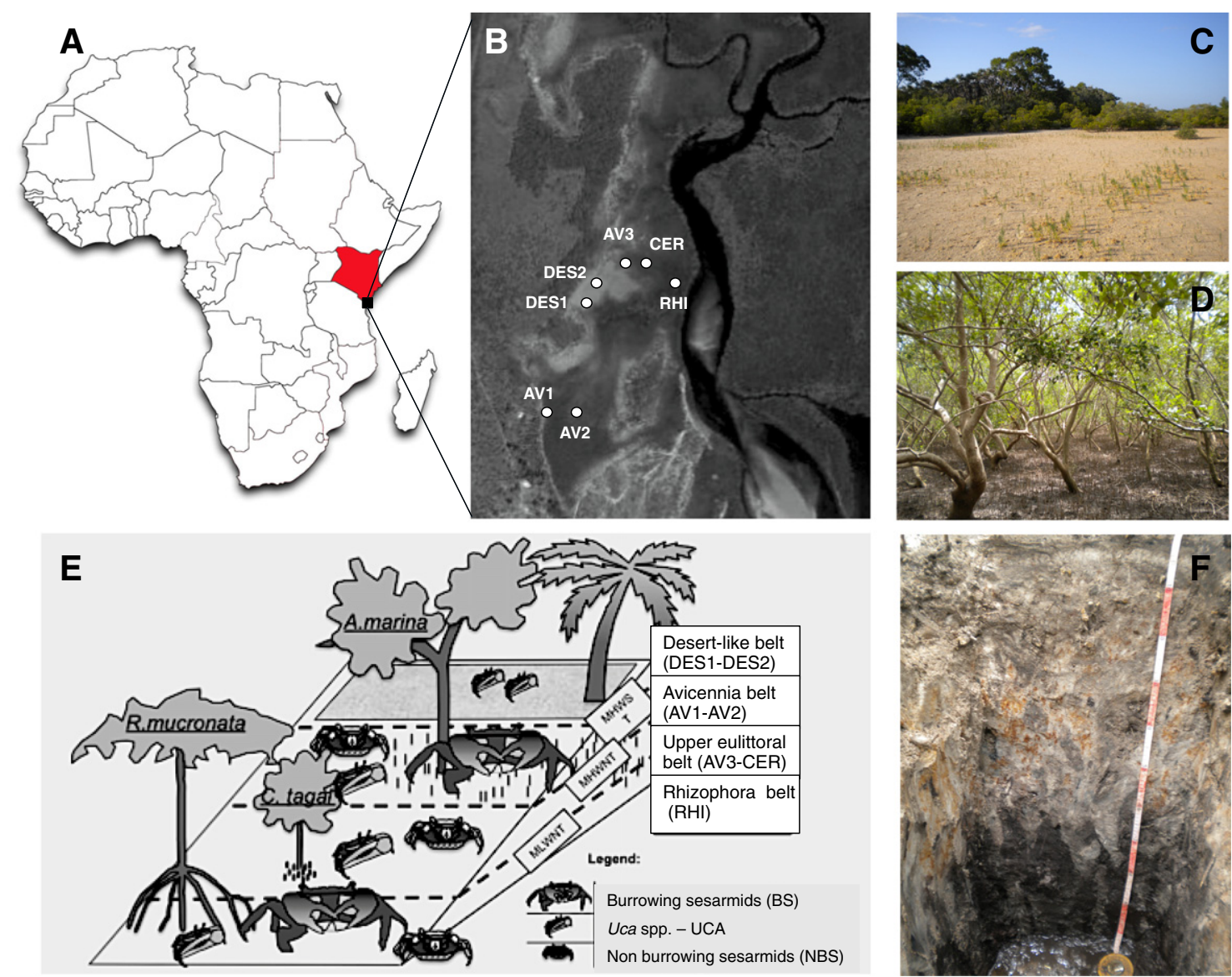

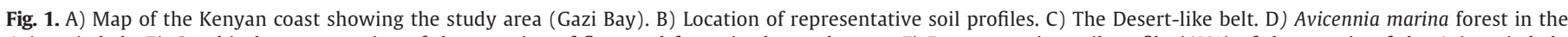

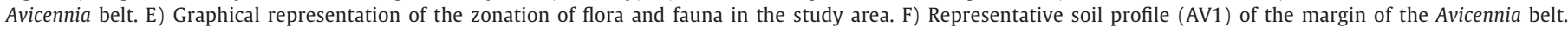
Redoximorphic features are evident.

used, according to species behaviour. For fiddler crabs, represented by Uca annulipes, Uca inversa, Uca chlorophthalmus and Uca urvillei, we applied the techniques proposed by Skov and Hartnoll (2001) and Cannicci et al. (2009). Individuals were first counted visually at each site, to assess the relative frequencies of the populations present in the quadrat. Then, crab burrows were counted in five random $50 \times 50 \mathrm{~cm}$ sub-quadrats to avoid underestimation of specimens not active on the surface during the visual crab counts. The density of each species was estimated from the burrow counting, calibrated with the species ratio obtained from the visual counting. Small sesarmids, represented by Chiromantes ortmanni, Chiromantes eulimene, Perisesarma guttatum and Parasesarma leptosoma, were counted visually throughout the quadrat. The density of large sesarmids, represented by Neosarmatium africanum (= Neosarmatium meinerti) (Ragionieri et al., 2012) and Neosarmatium smithi was assessed by counting the operational burrows in the quadrats, since these refuges are occupied by single crabs (Fratini et al., 2000; Skov and Hartnoll, 2002).

To convert crab abundance into biomass, we collected a total of 463 crabs of the following species: C. eulimene (22), C. ortmanni (36), P. guttatum (73), U. annulipes (117), U. inversa (47), U. chlorophthalmus, U. urvillei (51), N. africanum (22) and N. smithi (42). Carapace width (CW) and length (CL) were measured using Vernier callipers; dry weight (DW) of all specimens was determined using a precision balance and sex was recorded. A strong correlation was found between crab size and DW, and an average DW was calculated for the various populations. The total biomass of each species was then estimated by multiplying average DW by the observed frequency of each species in the stations.

Matter stored in the burrows of the two main leaf-litter consumers of Gazi Bay mangroves, N. africanum and N. smithi, was also estimated. Ten dens per species were excavated along their funnel down to the main chambers, always touching the water table, collecting all matter found along the burrow. The stored matter could be divided into 4 main groups: mangrove leaf-litter, propagules, seeds, shells, including both mollusc shells and crustacean carapaces, presumably preyed by the crab. The average dry weight of stored matter found per den was then multiplied by the average number of holes found per square metre on the transect, to approximate the average dry weight of matter stored by sesarmids per square metre of Gazi forest. Temperature and oxygen saturation of the water at the bottom of the dens were measured at low tide.

\subsection{Soil description}

Horizon types were indicated using the nomenclature from Soil Survey Staff (2010). Soil colours were identified by direct comparison with Munsell soil colour tables; Munsell notation is based on three colour dimensions: e.g. 7.5YR 4/2, hue (a specific colour; eg. 7.5YR), value (lightness; eg. 4) and chroma (colour saturation; eg. 2).

Since most pedogenic processes in the described soils were strongly affected by water saturation, we resume the main characters of the colour patterns related to hydromorphic soil conditions. The gleyic colour pattern appears in those soils that are influenced by a fluctuating water table. During water table lowering, a redox gradient sets between the larger pores and the groundmass. Within the groundmass, Fe is either immobilized into insoluble Fe (II) compounds or translocated, leading to the absence of red colour components. Translocated Fe can oxidize and becomes concentrated on the surfaces of large pores, in the shape of the so-called "rusty channels". Conversely, the stagnic colour pattern characterises those soils that get temporarily saturated by 
surface water, which cannot be drained readily. In these soils, the spatial distribution of reducing and oxidising microenvironments is reversed, so that they show grey mottling on pore surfaces and red colours in the interior of the groundmass (IUSS Working Group WRB, 2006; Soil Survey Staff, 2010). When gleying process has taken place, the symbol "g" is used with B or C mineral horizons (e.g. Bg).

Oxidisable sulphur compounds, such as pyrite $\left(\mathrm{FeS}_{2}\right)$, accumulate in submerged soils and form sulphuric acid when exposed to aerobic conditions. Acidification may induce formation of iron and aluminium sulphates. An intermediate product of sulphide oxidation is the mineral jarosite $\left(\mathrm{KFe}_{3}\left(\mathrm{SO}_{4}\right)_{2}(\mathrm{OH})_{6}\right)$ which segregates under strongly oxidising and severely acid conditions, forming yellow concentrations. Jarosite is ultimately hydrolysed, at higher $\mathrm{pH}$ values, to goethite $(\mathrm{FeO}(\mathrm{OH}))$ and haematite $\left(\mathrm{Fe}_{2} \mathrm{O}_{3}\right)$, which may deposit in the soil as orange and red mottles, coatings, pipes and nodules (Dent, 1986; Soil Survey Staff, 2010). The mottled colours indicate the presence of intermediate products of sulphide oxidation, thus they were used to interpret different stages of sulphur oxidation. The lowercase letter " $\mathrm{j}$ " used as suffix of mineral horizon (e.g. $\mathrm{Bj}$ ) means that an accumulation of jarosite has been observed (Soil Survey Staff, 2010).

\subsection{Soil analyses}

Bulk samples were air-dried, sieved ( $<2 \mathrm{~mm}$ ) and homogenized. $\mathrm{pH}$ was measured potentiometrically. To analyse particle size sand was separated, after dispersion, by wet sieving. Clay and silt were determined by the pipette method (Gee and Bauder, 1986). For the determination of soil bulk density, samples taken with a known volume metal corer were oven dried at $105^{\circ} \mathrm{C}$ and weighed. The bulk density was calculated as the ratio of the dry mass of soil sample to its volume. Soil organic nitrogen and carbon were determined by a CNS Analyser series Flash EA 1112.

Soil organic C stored in the soil was calculated by the following formula:

$\mathrm{SOC}_{\text {tot }}=\sum_{1}^{n}(\mathrm{OC} \times \mathrm{BD} \times \mathrm{Dh})$

where SOC is the soil organic carbon stock $\left(\mathrm{kg} \mathrm{m}^{-2}\right), \mathrm{OC}$ is the organic carbon content for each depth interval $\left(\mathrm{mg} \mathrm{g}^{-1}\right)$, BD is the bulk density $\left(\mathrm{g} \mathrm{cm}^{-3}\right.$ ) and Dh is the soil thickness interval ( $\mathrm{m}$; Andreetta et al., 2011).

\subsection{Radiocarbon dating and stable isotope analyses}

Radiocarbon dating and stable isotope analysis were carried out at Beta Analytics, Miami, U.S. The samples were sieved with a $180 \mu \mathrm{m}$ sieve. Plant material caught in the sieve has been pre-treated through an acid wash to remove carbonate and an alkali wash to remove mobile humic acids, and then has been dated. Radiocarbon ages in this paper were corrected for isotopic fractionation, but were not calibrated and converted into calendar ages for the purpose of comparison with literature data.

\subsection{Statistical analysis}

The Kolmogorov-Smirnov test was used to test normality. SOC was not normally distributed, then differences were tested by the nonparametric Kruskal-Wallis test. A full factorial Permutational Analysis of Variance (PERMANOVA, Anderson, 2001a,b) was used to test the null hypothesis of no relationship between SOC content and presence of crabs in the sampled plots. Crabs were divided into two functional groups: microalgal feeders (UCA) and mangrove litter consumers (Burrowing Sesarmid = BS and Non-Burrowing Sesarmid = NBS), and this 3-level factor (BS, UCA, NBS) was defined as fixed and orthogonal. Relationships between crab assemblage and SOC found at different depths were tested by Distance-based Linear Model analysis (DistLM, Anderson, 2001b) using as selected criterion AIC (Akaike' criterion) (Johnson and Omland, 2004) and as select procedure 'all specified' (Anderson, 2008). All data are expressed as means $\pm \mathrm{SE}$; the analyses were performed using the PERMANOVA + routines for PRIMER 6 (Anderson, 2008).

\section{Results}

\subsection{Crab and burrowed material biomass standing stock estimation}

High crabs standing stock was found in the Avicennia belt and the Rhizophora belt, whilst low values were found in the upper eulittoral and Desert-like belts (Fig. 3B). In the Avicennia belt $N$. africanum was the dominant species with an average burrow density of 22 per $\mathrm{m}^{2}$, whilst in the Rhizophora belt, $N$. smithii (approximately 10 burrows per $\mathrm{m}^{2}$ ) and $U$. urvillei are well represented, and thus important in biomass estimation.

Mainly Uca spp. represented by U. inversa and U. annulipes, were found in the Desert-like and Ceriops belts, while sesarmids, in particular the burrowing species, seem to avoid these places.

Standing stock matter burrowed by crab activity analyzed for the $N$. smithi and $N$. africanum is up to $45 \mathrm{~g} \mathrm{~m}^{-2}$ dry weight (Fig. 4), 1.4 times and 4 times their own body weight, and was predominantly made up by leaf-litter and propagules. Other organic material as nonmangrove seeds and shells (including gastropods shells, crab carapaces and rests of other crustaceans) was stored in lesser quantities.

The value of oxygen saturation was lower in the water that cover the bottom of Neosarmatium burrows $(17 \pm 3.7 \%)$ than those of Uca spp. $(38.2 \pm 1.1 \%)$. A constant water temperature of $30 \pm 0.5{ }^{\circ} \mathrm{C}$ was found.

\subsection{Soil morphological characters}

Descriptions of representative soil profiles are summarized in Table 1. Profiles DES1 (Fig. 2A) and DES2 (Fig. 2B), in the Desert-like belt, show sandy E horizons, poor in organic matter, and underlying thick Btgj horizons showing small, yellow jarosite spots (suffix "j") and pronounced redoximorphic features, including Fe-enriched root traces (rusty channels, gleyic colour pattern (suffix "g")) and Fe-depleted ones (stagnic colour pattern). The darker deepest horizons contain woody fragments (roots or stems).

In the Avicennia belt, profile AV2 is located in the middle of the A. marina stand while AV1 (Fig. 2C) is close to the landward edge. They are thus differently influenced by tidal flooding, exhibiting different morphological characters. AV2 is homogenously brown (7.5YR 4/2) to very dark grey (10YR 3/1) in the deepest horizon with abundant yellowish-red (5YR 4/6) rusty channels. On the other hand AV1 displays complex redoximorphic pedofeatures. Soil matrix is pale coloured with drab iron-depleted zones containing abundant rusty channels. The deepest horizon, Bg2, is black (10YR 2/1) and rich in organic matter. Crab burrows are coated by well preserved $A$. marina leaves.

Moving to the upper eulittoral belt, in CER and AV3 soils carbon rich $\mathrm{B}$-horizons are overlain by light coloured $\mathrm{E}$ horizons. Colour is light olive brown (2.5Y 5/3) and light yellowish brown (10YR 6/4), respectively, with few yellowish red (5YR 4/6 and 5YR 5/8) rusty channels and other small oximorphic mottles. In both profiles, the Bg1 horizon exhibits brown to pale brown mottling of the dark soil matrix.

Soils represented by RHI profile, in Rhizophora belt, are the closest to the coastline and the most affected by inundation and waterlogging. Horizons are rich in organic matter and dark coloured (10YR 3/1) with strong brown (7.5YR 4/6) rusty channels concentrated in the A horizon. Abundant burrows highlight an intense crab activity.

\subsection{Soil carbon storage}

Soil C and N contents are low to very low (Table 2), and all horizons are definitely mineral in character. Bulk density (Table 3) showed a minimum average of $0.64 \mathrm{~g} \mathrm{~cm}^{-3}$ for the Rhizophora belt and a 

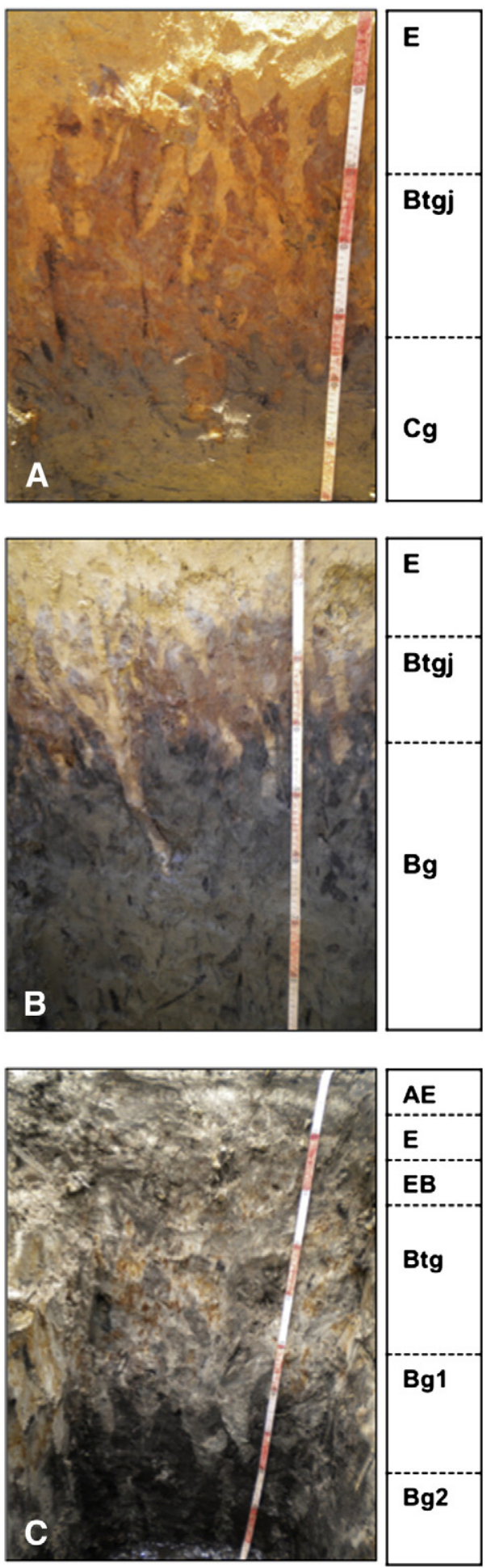

Fig. 2. Soil profiles A) DES1 and B) DES2 in the desert-like belt; C) soil profile AV1 in the Avicennia belt. Btgj horizons in DES1 and DES2 profiles evidence common yellow jarosite concentrations (j) and abundant reddish oxidation features (g). In AV1 soil profile, Btg and Bg1 are bleached sandy horizons coloured by iron oxide ( $\mathrm{g})$.

maximum of $2.12 \mathrm{~g} \mathrm{~cm}^{-3}$ for the Desert-like belt soils. Sampling for bulk densities was problematic for the deepest intervals in the Rhizophora and Avicennia belts, due to the water table. As organic matter content is widely considered one of the main factors influencing soil bulk density (Adams, 1973; Manrique and Jones, 1991), a regression

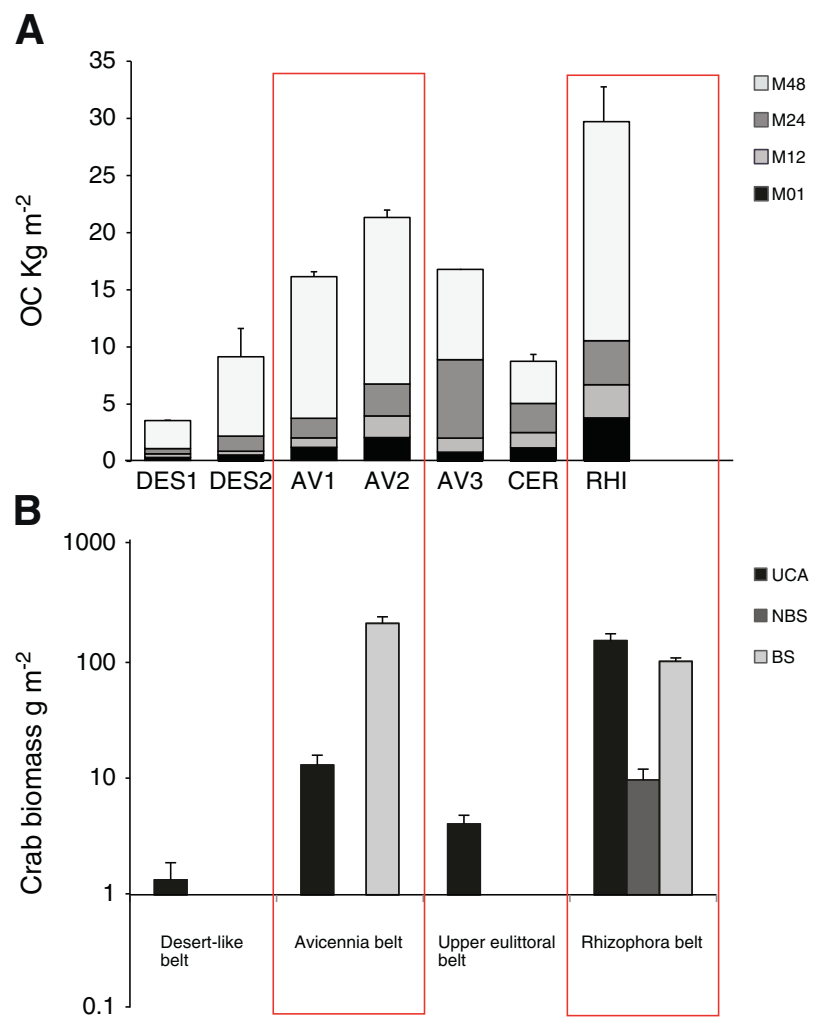

Fig. 3. SOC depth distribution (A), expressed as $\mathrm{kg} \mathrm{m}^{-2}$ for each depth interval; M01: 0-10 cm, M12: 10-20 cm, M24: 20-40 cm and M48: 40-80 cm. Crab biomass distribution (B) expressed as log of grams of Dry Weight per $\mathrm{m}^{2}$ of mangrove forest floor UCA: fiddler crabs, NBS: Non Burrowing Sesarmid Crabs; BS: Burrowing Sesarmids.

of $\mathrm{BD}$ and $\mathrm{C}$ concentration was used to estimate the missing BDs. Data collected during this study yielded the following quantitative relationship, with $\mathrm{r}^{2}=0.79$ (Fig. $\mathrm{S} 1$, see supplement).

$\mathrm{BD}=-0.314 \ln \left(\mathrm{OCmg} \mathrm{g}^{-1}\right)+2.0585$

As shown in Fig. 3A, SOC distribution is not homogeneous among belts. Although the desert-like and Avicennia belts exhibit a similar pattern, showing the highest $C$ storage in the deepest interval, the Avicennia belt is clearly richer in SOC along the whole soil profile, while the lowest overall carbon stocks is located in the Desert-like

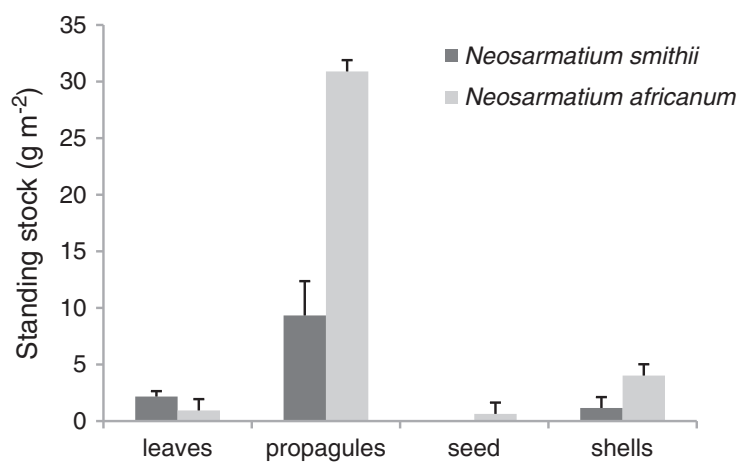

Fig. 4. Assessment of burrow content standing stock per $\mathrm{m}^{2}$ of mangrove floor. Data are related to the main burrower species Neosarmatium africanum and Neosarmatium smithii thriving respectively in Avicennia belt and Rhizophora belt. 
Table 1

Description of representative soil profiles.

\begin{tabular}{|c|c|c|c|c|c|c|c|c|}
\hline Profile & Horizon & Depth $(\mathrm{cm})$ & Colour & Reduction features, colour & Oxidation features, colour & Clay coatings & Smell $^{\mathrm{a}}$ & Other \\
\hline \multirow[t]{3}{*}{ DES1 } & $\mathrm{E}$ & $0-18 / 20$ & $\begin{array}{l}\text { Brownish yellow } \\
(10 Y R \text { 6/6) }\end{array}$ & & & & & $\begin{array}{l}\text { Common crabs; } \\
\text { tortoise shell }\end{array}$ \\
\hline & Btgj & $18 / 20-49 / 60$ & $\begin{array}{l}\text { Brownish yellow } \\
(10 Y R \text { 6/8) }\end{array}$ & $\begin{array}{l}\text { Common, light brownish } \\
\text { grey (10YR 6/2) }\end{array}$ & $\begin{array}{l}\text { Abundant, red } \\
\text { (10R 4/6), } \\
\text { yellowish brown } \\
\text { (10YR 5/8) }\end{array}$ & Common & & $\begin{array}{l}\text { E horizon tongues; } \\
\text { few yellow mottles; } \\
\text { plant debris }\end{array}$ \\
\hline & $\mathrm{Cg}$ & $49 / 60-90+$ & $\begin{array}{l}\text { Light olive brown } \\
(2.5 Y 5 / 3)\end{array}$ & & & & & $\begin{array}{l}\text { Btgj horizon tongues; } \\
\text { abundant plant debris }\end{array}$ \\
\hline \multirow[t]{3}{*}{ DES2 } & $\mathrm{E}$ & $0-15 / 20$ & Yellow (10YR 7/6) & $\begin{array}{l}\text { Few, pale olive ( } 5 \text { Y } 6 / 3) \text {, } \\
\text { bluish black }(2.5 / 5 \mathrm{~PB})\end{array}$ & & Common & & $\begin{array}{l}\text { Common crabs; } \\
\text { tortoise shell }\end{array}$ \\
\hline & Btgj & $15 / 20-35 / 50$ & $\begin{array}{l}\text { Strong brown } \\
(7.5 Y R 5 / 8)\end{array}$ & & $\begin{array}{l}\text { Common, brownish yellow } \\
\text { (10YR 6/8), reddish brown } \\
(5 Y R 4 / 4)\end{array}$ & Few & & $\begin{array}{l}\text { Common tongues from } \\
\text { E horizon; few } \\
\text { yellow mottles }\end{array}$ \\
\hline & $\mathrm{Bg}$ & $35 / 50-110+$ & $\begin{array}{l}\text { Dark greyish brown } \\
(2.5 Y 4 / 2)\end{array}$ & & & & & Common plant debris \\
\hline \multirow[t]{7}{*}{ AV1 } & $\mathrm{AE}$ & $0-2 / 3$ & $\begin{array}{l}\text { Very dark greyish } \\
\text { brown (10YR 3/2) }\end{array}$ & $\begin{array}{l}\text { Spots, light } \\
\text { yellowish brown } \\
(2.5 Y \text { Y } 6 / 3) \text {, greyish } \\
\text { brown }(2.5 Y 5 / 2)\end{array}$ & & & & \\
\hline & $\mathrm{E}$ & $2 / 3-5 / 6$ & $\begin{array}{l}\text { Light yellowish brown } \\
(2.5 Y \text { Y } 6 / 3)\end{array}$ & & Few & & & \\
\hline & EB & $5 / 6-20 / 30$ & Brown (10YR 5/3) & Few & $\begin{array}{l}\text { Common, yellowish } \\
\text { red (5YR 4/6) }\end{array}$ & Common & & $\begin{array}{l}\text { Common crab channels } \\
\text { and droppings }\end{array}$ \\
\hline & Btg & $20 / 30-50 / 60$ & $\begin{array}{l}\text { Light brownish grey } \\
(10 \text { YR 6/2) }\end{array}$ & Common & $\begin{array}{l}\text { Common, yellowish } \\
\text { red (5YR 4/6) }\end{array}$ & Common & & $\begin{array}{l}\text { Few plant debris; abundant } \\
\text { crab channels } 2.5 / 5 \mathrm{~PB} \text {, } \\
10 \text { YR } 4 / 1\end{array}$ \\
\hline & Bg1 & $50 / 60-55 / 80$ & $\begin{array}{l}\text { Greyish brown } \\
(10 \text { YR } 5 / 2)\end{array}$ & Common & & & & \\
\hline & Bg2 & $55 / 80-115+$ & Black (10YR 2/1) & Common & & & yes & Abundant plant debris \\
\hline & Auger & $115-165$ & $\begin{array}{l}\text { Very dark grey } \\
(7.5 Y R 3 / 1)\end{array}$ & & & & yes & Abundant plant debris \\
\hline \multirow[t]{4}{*}{ AV2 } & $\mathrm{AE}$ & $0-3 / 8$ & Brown (7.5YR 4/2) & Few & Few & Few & & \\
\hline & $\operatorname{Bg} 1$ & $3 / 8-48 / 55$ & Brown (7.5YR 4/2) & & $\begin{array}{l}\text { Common, yellowish red } \\
\text { (5YR 4/6), dark reddish } \\
\text { brown }(5 Y R 3 / 4) \text {, }\end{array}$ & Few & & \\
\hline & Bg2 & $48 / 55-55+$ & - & & & & yes & Too wet to describe \\
\hline & Auger & $40-80$ & $\begin{array}{l}\text { Very dark grey } \\
(10 \text { YR 3/1) }\end{array}$ & & & & & \\
\hline \multirow[t]{3}{*}{ AV3 } & $\mathrm{E}$ & $0-15 / 18$ & $\begin{array}{l}\text { Light yellowish brown } \\
\text { (10YR 6/4) }\end{array}$ & $\begin{array}{l}\text { Common, grey } \\
(10 Y R 5 / 1)\end{array}$ & $\begin{array}{l}\text { Common, yellowish red } \\
\text { (5YR 5/8, 7.5YR 5/8) }\end{array}$ & & & $\begin{array}{l}\text { Common channels } \\
\text { 10YR 5/1 }\end{array}$ \\
\hline & Bg1 & $15 / 18-48$ & $\begin{array}{l}\text { Very dark grey } \\
(10 \text { YR } 3 / 1)\end{array}$ & & Few, brown (10YR 5/3) & & yes & Common plant debris \\
\hline & Bg2 & $48-76+$ & $\begin{array}{l}\text { Greyish brown } \\
(10 \text { YR } 5 / 2)\end{array}$ & & & & yes & Common plant debris \\
\hline \multirow[t]{3}{*}{ CER } & $\mathrm{E}$ & $0-15 / 22$ & $\begin{array}{l}\text { Light yellowish brown } \\
(2.5 Y 6 / 3)\end{array}$ & $\begin{array}{l}\text { Common, dark grey } \\
(10 \mathrm{YR} 4 / 1)\end{array}$ & $\begin{array}{l}\text { Common, yellowish } \\
\text { red (5YR 4/6), } \\
\text { light olive brown } \\
(2.5 Y 5 / 3)\end{array}$ & & & Common crab channels \\
\hline & Bg1 & $15 / 22-52 / 100$ & Dark grey $(2.5 Y$ 4/1) & & $\begin{array}{l}\text { Few, yellowish brown } \\
\text { (10YR 5/8), } \\
\text { pale brown (10YR 6/3) }\end{array}$ & Few & & \\
\hline & Bg2 & $52 / 100-120+$ & $\begin{array}{l}\text { Light olive brown } \\
(2.5 \mathrm{Y} 5 / 3)\end{array}$ & $\begin{array}{l}\text { Common, dark grey } \\
(2.5 Y \text { 4/1) }\end{array}$ & & & yes & \\
\hline \multirow[t]{2}{*}{ RHI } & $\mathrm{Ah}$ & $0-27$ & $\begin{array}{l}\text { Very dark grey } \\
\text { (10YR 3/1) }\end{array}$ & & $\begin{array}{l}\text { Common, strong brown } \\
(7.5 Y R 4 / 6)\end{array}$ & & & Crab channels \\
\hline & $\begin{array}{l}\text { Bgh } \\
\text { Auger }\end{array}$ & $\begin{array}{l}27-48+ \\
40-80\end{array}$ & & & & & & Too wet to describe \\
\hline
\end{tabular}

Horizons: $\mathrm{A}=$ mineral horizon that formed at the surface.

$\mathrm{E}=$ mineral horizons in which the main feature is loss of silicate clay, iron, aluminium and organic carbon, leaving a concentration of sand and silt particles.

$\mathrm{B}=$ horizons that formed below an $\mathrm{A}$, E, or O horizon and are dominated by obliteration of all or much of the original rock or parent material structure.

$\mathrm{C}=$ horizons that are little affected by pedogenic processes.

$\mathrm{AE}$ and $\mathrm{EB}=$ transitional horizons.

Suffix symbols: $\mathrm{g}=$ strong gleying; $\mathrm{j}=$ accumulation of jarosite; $\mathrm{t}=$ accumulation of silicate clay; $\mathrm{h}=$ accumulation of organic matter.

a Smell of hydrogen sulphide.

belt. Here the SOC storage in the upper layers of the DES1 and DES2 profiles (M01 and M12, 0-20 cm) is significantly lower compared to the other sites $(p=0.005$ with respect to AV1 and $p=0.013$ with respect to AV2, CER and RHI).

Among soils covered by the same vegetation type, but belonging to different belts (AV1, AV2 and AV3), significant differences were found in SOC between the different soil depth intervals. In AV3, SOC in the $20-40 \mathrm{~cm}$ of soil interval is significantly higher $(p=0.05)$ than in
AV1 and AV2. Further, a significantly higher SOC $(p=0.034)$ was observed in AV2 vs. AV1 in the $0-20 \mathrm{~cm}$ soil interval. In the Upper eulittoral belt, here represented by AV3 and CER, the largest amount of SOC is stored in the $20-80 \mathrm{~cm}$ intervals. SOC in the deepest soil layer $(40-80 \mathrm{~cm})$ is significantly higher $(p=0.003)$ in the Avicennia and Rhizophora belts (AV1, AV2 and RHI) than in the Upper eulittoral and Desert-like belts (CER, AV3, DES1 and DES2). The Rhizophora belt is the richest overall in SOC. 
Table 2

Soil properties.

\begin{tabular}{|c|c|c|c|c|c|c|c|}
\hline Profile & Horizon & $\begin{array}{l}\text { Sand } \\
(\%)\end{array}$ & $\begin{array}{l}\text { Clay } \\
(\%)\end{array}$ & $\mathrm{pH}$ & $\begin{array}{l}\mathrm{C} \\
(\%)\end{array}$ & $\begin{array}{l}\mathrm{N} \\
(\%)\end{array}$ & $\mathrm{C} / \mathrm{N}$ \\
\hline \multirow[t]{3}{*}{ DES1 } & $\mathrm{E}$ & 92.6 & 4.0 & 8.9 & 0.2 & 0.03 & 18.6 \\
\hline & Btgj & 83.1 & 14.2 & 8.1 & 0.1 & 0.01 & 9.8 \\
\hline & $\mathrm{Cg}$ & 83.7 & 12.2 & 3.4 & 0.3 & 0.02 & 16.8 \\
\hline \multirow[t]{3}{*}{ DES2 } & $\mathrm{E}$ & 92.5 & 3.4 & 8.9 & 0.3 & 0.01 & 28.0 \\
\hline & Btgj & 86.5 & 9.2 & 6.6 & 0.5 & 0.02 & 19.6 \\
\hline & $\mathrm{Bg}$ & 75.3 & 11.5 & 3.3 & 1.3 & 0.10 & 28.2 \\
\hline \multirow[t]{7}{*}{ AV1 } & $\mathrm{AE}$ & 84.7 & 11.7 & 7.5 & 1.1 & 0.10 & 14.1 \\
\hline & $\mathrm{E}$ & 93.3 & 3.5 & 7.3 & 1.1 & 0.10 & 14.1 \\
\hline & $\mathrm{EB}$ & 86.3 & 6.7 & 6.9 & 0.6 & 0.10 & 11.5 \\
\hline & Btg & 87.5 & 6.7 & 6.6 & 0.5 & 0.03 & 12.8 \\
\hline & Bg1 & 81.8 & 8.5 & 5.0 & 2.2 & 0.10 & 27.3 \\
\hline & Bg2 & 70.9 & 20.2 & 3.0 & 6.0 & 0.20 & 37.6 \\
\hline & Auger 115-165 & & & & 5.2 & 0.10 & 47.1 \\
\hline \multirow[t]{5}{*}{ AV2 } & $\mathrm{AE}$ & 83.5 & 6.3 & 7.0 & 1.6 & 0.10 & 13.4 \\
\hline & Bg1 & 69.4 & 9.2 & 6.8 & 1.5 & 0.10 & 12.3 \\
\hline & Bg2 & 71.4 & 12.7 & 6.3 & 0.9 & 0.10 & 13.2 \\
\hline & Auger $40-80$ & & & & 4.1 & 0.20 & 23.9 \\
\hline & Auger 80-120 & & & & 4.3 & 0.20 & 28.5 \\
\hline \multirow[t]{3}{*}{ AV3 } & $\mathrm{E}$ & 86.5 & 8.0 & 7.1 & 0.5 & 0.04 & 13.8 \\
\hline & Bg1 & 78.6 & 10.7 & 2.9 & 2.7 & 0.10 & 32.1 \\
\hline & $\mathrm{Bg} 2$ & 73.7 & 11.5 & 3.1 & 1.3 & 0.04 & 34.3 \\
\hline \multirow[t]{3}{*}{ CER } & $\mathrm{E}$ & 96.1 & 2.9 & 7.0 & 1.0 & 0.10 & 18.8 \\
\hline & Bg1 & 74.3 & 16.1 & 3.1 & 0.9 & 0.03 & 23.9 \\
\hline & Bg2 & 72.1 & 18.7 & 3.5 & 0.5 & 0.02 & 20.0 \\
\hline \multirow[t]{3}{*}{ RHI } & $\mathrm{Ah}$ & 79.2 & 15.0 & 6.4 & 5.1 & 0.30 & 16.6 \\
\hline & Bgh & 79.7 & 17.7 & 4.2 & 2.8 & 0.20 & 16.4 \\
\hline & Auger $40-80$ & & & & 5.4 & 0.20 & 26.0 \\
\hline
\end{tabular}

Table 3

Soil properties relevant to soil carbon storage (Depth, OC and BD) and SOC $\left(\mathrm{kg} \mathrm{m}^{-2}\right)$ for each depth interval of Gazi Bay soils. OC and BD are expressed as a mean of three replicates.

\begin{tabular}{|c|c|c|c|c|}
\hline Site & $\begin{array}{l}\text { Depth } \\
(\mathrm{cm})\end{array}$ & $\begin{array}{l}\mathrm{OC} \\
\left(\mathrm{mg} \mathrm{g}^{-1}\right)\end{array}$ & $\begin{array}{l}\mathrm{BD} \\
\left(\mathrm{g} \mathrm{cm}^{-3}\right)\end{array}$ & $\begin{array}{l}\mathrm{SOC} \\
\left(\mathrm{kg} \mathrm{m}^{-2}\right)\end{array}$ \\
\hline \multirow[t]{5}{*}{ DES1 } & $0-10$ & 2.05 & 1.65 & 0.34 \\
\hline & $10-20$ & 1.59 & 1.98 & 0.32 \\
\hline & $20-40$ & 1.20 & 1.92 & 0.46 \\
\hline & $40-80$ & 2.90 & 2.12 & 2.45 \\
\hline & Total & & & 3.57 \\
\hline \multirow[t]{5}{*}{ DES2 } & $0-10$ & 3.51 & 1.56 & 0.55 \\
\hline & $10-20$ & 1.99 & 1.64 & 0.33 \\
\hline & $20-40$ & 4.31 & 1.53 & 1.323 \\
\hline & $40-80$ & 12.80 & 1.36 & 6.94 \\
\hline & Total & & & 9.15 \\
\hline \multirow[t]{5}{*}{ AV1 } & $0-10$ & 8.47 & 1.45 & 1.22 \\
\hline & $10-20$ & 6.23 & 1.26 & 0.83 \\
\hline & $20-40$ & 5.72 & 1.50 & 1.72 \\
\hline & $40-80$ & 22.21 & 1.40 & 12.39 \\
\hline & Total & & & 16.15 \\
\hline \multirow[t]{5}{*}{ AV2 } & $0-10$ & 17.45 & 1.23 & 2.08 \\
\hline & $10-20$ & 16.30 & 1.20 & 1.89 \\
\hline & $20-40$ & 11.94 & 1.34 & 2.80 \\
\hline & $40-80$ & 40.71 & ${ }^{\mathrm{a}} 0.89$ & 14.57 \\
\hline & Total & & & 21.33 \\
\hline \multirow[t]{5}{*}{ AV3 } & $0-10$ & 5.42 & 1.48 & 0.80 \\
\hline & 10-20 & 8.56 & 1.44 & 1.23 \\
\hline & $20-40$ & 26.93 & 1.27 & 6.86 \\
\hline & $40-80$ & 13.04 & 1.52 & 7.90 \\
\hline & Total & & & 16.79 \\
\hline \multirow[t]{5}{*}{ CER } & $0-10$ & 8.19 & 1.44 & 1.18 \\
\hline & $10-20$ & 10.96 & 1.22 & 1.34 \\
\hline & $20-40$ & 8.73 & 1.46 & 2.55 \\
\hline & $40-80$ & 5.44 & 1.69 & 3.69 \\
\hline & Total & & & 8.75 \\
\hline \multirow[t]{5}{*}{ RHI } & $0-10$ & 48.97 & 0.77 & 3.80 \\
\hline & 10-20 & 42.84 & 0.69 & 2.90 \\
\hline & $20-40$ & 28.83 & 0.64 & 3.85 \\
\hline & $40-80$ & 63.83 & ${ }^{\mathrm{a}} 0.75$ & 19.16 \\
\hline & Total & & & 29.72 \\
\hline
\end{tabular}

a BD Estimated from Eq. (1).
3.4. Stable isotopic analyses and radiocarbon dating of deeply buried organic matter

Radiocarbon dating (Table 4) focused on profiles DES2, AV1 and AV3, representative of Desert-like belt, Avicennia belt and Upper eulittoral belt, respectively. These profiles showed a large carbon stock in the deepest examined layers, which contained plant residues. Notwithstanding similar depth distributions, ages were quite different. Deeply buried OM in DES2 and AV3 soils has conventional ${ }^{14} \mathrm{C}$ ages of $3850 \pm 3 \mathrm{yr}$ BP and $2270 \pm 30 \mathrm{yr}$ BP, respectively. AV1 buried material is instead modern, with a $103.0 \pm 0.4$ percentage modern carbon (pMC), indicating that it is younger than about 1950.

Low $\delta^{13} \mathrm{C}$ and high $\mathrm{C} / \mathrm{N}$ ratio suggest an arboreal origin, compatible with mangrove vegetation.

\subsection{Macrobenthos influence on soil organic carbon storage}

A highly significant difference in SOC content was found between belts dominated by different functional groups of crabs $(F=21.631$; $\mathrm{df}=3 ; p<0.0001)$. Post-hoc tests showed that all the SOC content were different in relation to the crab assemblage in the experimental plots. Furthermore, the DistLM analysis showed that the presence of different crab assemblages significantly affected SOC. Although in the marginal test NBS, UCA and BS showed a statistically significant contribution to SOC content, BS and UCA were the most important variables in sequential test discriminating SOC storage, accounting together for $79 \%$ of the total variance (Table 5 ).

\section{Discussion}

This study confirms that mangrove soils have a significant role as a place for carbon storage, which varies considerably, even at small scale, both spatially and with depth. Heterogeneity is partially explained by dominance of different key-bioturbator species. Although such other factors as vegetation and inundation times are recognised as controls of SOC in these ecosystems, this study highlighted evidence, based on soil features and dating, of the faunal role on carbon storage.

The highest crab biomass was found in the Avicennia and Rhizophora belts, where, respectively, N. africanum and U. urvillei plus N. smithii are the dominant contributors to crab standing stock. Conversely, very low biomass was recorded in the Upper Eulittoral and Desert-like belts. Uca spp. tend to utilize the Desert-like belt as foraging ground (Bartolini et al., 2011), rather than as burrowing area, remaining in shallow holes during high tide. In Gazi Bay, the Upper eulittoral belt is a transition zone between the Avicennia and Rhizophora belts, where vegetation structure is less complex making the ground less suitable for burrowing. The present data confirm the crab distribution patterns well known in East African mangroves (Derijard, 1966; Hartnoll, 1975; Macnae, 1968; Macnae and Kalk, 1962), but they are amongst the first attempts to produce data on crab standing stock. Previous studies focused on Malaysian (Macintosh, 1977; Macintosh and De Silva, 1984) and, more recently, Brazilian systems (Koch and Wolff, 2002), while for East Africa standing stock and biomass were studied only for sesarmids and gave highly variable data, 150-750 $\mathrm{g} \mathrm{m}^{-2}$ (Emmerson and McGwynne, 1992; Skov and Hartnoll, 2002; Wells, 1984). Comparing our data with the above mentioned studies reveals that East African

Table 4

Radiocarbon dating of deep buried organic matter.

\begin{tabular}{llll}
\hline Soil profile & Horizon & $\begin{array}{l}\delta^{13} \mathrm{C} \\
(\% \circ \mathrm{PDB})\end{array}$ & $\begin{array}{l}\text { Age } \\
\left({ }^{14} \mathrm{Cyr} \mathrm{BP}\right)\end{array}$ \\
\hline DES2 & Bg & -26.3 & $3850 \pm 30 \mathrm{BP}$ \\
AV3 & Bg2 & -26.4 & $2270 \pm 30 \mathrm{BP}$ \\
AV1 & Bg2 & -26.1 & $103.0 \pm 0.4 \mathrm{pMC}$ \\
\hline
\end{tabular}

$\mathrm{BP}=$ before present; $\mathrm{pMC}=$ percentage modern carbon 
Table 5

Test for relationships between SOC content for each layer and faunal macrobenthos functional group assemblage inhabiting it, using non-parametric multivariate multiple regression analysis (DistLM). Marginal (a) and sequential (b) tests, where amount explained by each variable added to model is conditional on variables already in the model.

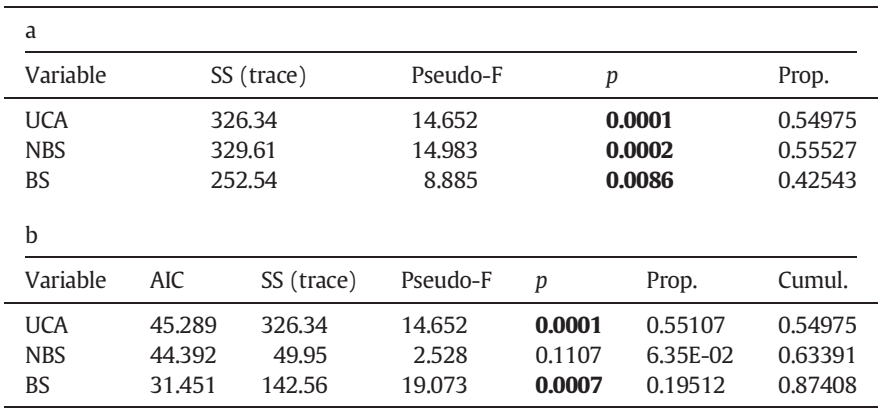

AIC: coefficient of regression, SS: sum of square, F: value of pseudo and its significance $p$, Prop: percentage of variance explained by each single variable, and cumulative percentage of variance explained and Cumul.: the sum of the variability explain by the variables. Bold characters indicate a statistically significant contribution to SOC storage.

mangrove systems, although low in diversity of crabs, show a very high standing stock, almost twice the maximum standing stock recorded in Brazil and in other mangrove around the world (Koch and Wolff, 2002; Nordhaus et al., 2009).

All soils in the transect contain sulphides, but the state of oxidation is highly variable. In the Btgj horizons of Desert-like belt soils (DES1 and DES2), yellow jarosite spots, from initial sulphide oxidation, and reddish oximorphic goethite mottles, from jarosite hydrolysis at higher $\mathrm{pH}$ values (Dent and Pons, 1995; Van Breemen, 1980) indicate oxidation. In soils of the Avicennia belt, signs of sulphide oxidation are less expressed. In AV1, goethite mottles are present in the Btg horizon, while sharp tonguing of the Btg into the Bg horizon was produced by bleaching of organic matter during sulphide oxidation. On the other hand, soils in the Rhizophora belt (RHI) are, as previously reported by Matthijs et al. (1999), strongly reduced (soil Eh of $-284 \pm 38 \mathrm{mV}$ ) with high sulphide concentration (0.3-4.6 mM). The distribution of $\mathrm{C}$ content in the sample population compares fairly well with the global distribution compiled by Kristensen et al. (2008). Few data on directly measured BDs are published for mangrove soils and they mostly concern organic soils (Donato et al., 2011; Page et al., 2011). Reported BD values range from 0.36 to $1.33 \mathrm{~g} \mathrm{~cm}^{-3}$ in North-Eastern Brazil (Sanders et al., 2010a,b), from 0.18 to $0.36 \mathrm{~g} \mathrm{~cm}^{-3}$ in Micronesia (Kauffman et al., 2011), from 0.56 to $1.37 \mathrm{~g} \mathrm{~cm}^{-3}$ for Southeast Australia (Howe et al., 2010) and from 0.20 to $0.92 \mathrm{~g} \mathrm{~cm}^{-3}$ for sites across the Indo-Pacific (Donato et al., 2011). Our data, instead, show a minimum average of $0.64 \mathrm{~g} \mathrm{~cm}^{-3}$ in the Rhizophora belt and a maximum of $2.12 \mathrm{~g} \mathrm{~cm}^{-3}$ for the Desert-like belt soils. This may be explained by high sand content (Table 2) and low OC concentrations (De Vos et al., 2005; Kaur et al., 2002). Hence, high BDs compensate for low OC concentration in influencing total SOC storage, determining high values of SOC in $\mathrm{kg} \mathrm{m}^{-2}$ even in these mineral soils. Total $\mathrm{C}$ storage is lower than reported by Fujimoto et al. (1999) and Donato et al. (2011), but comparable to that reported by Sanders et al., 2010a, b.

SOC storage in the upper part of the soil (M01 and M12, 0-20 cm) is significantly lower in the Desert-like belt (DES1 and DES2) than in all other sites. This is likely due to lack of vegetation and absence of the less reactive mangrove detritus. Here, microphytobenthos may be the main source of organic carbon (Kristensen et al., 2011; Middelburg et al., 1996). Although microphytobenthos supplies labile detritus and the activity of crabs in this site is high compared to other localities (Bartolini et al., 2011; Cannicci et al., 2009), a relatively high amount of organic carbon is still present. This might be due to incomplete algal removal by fiddler crabs during the sorting activity, as was previously found by comparing chlorophyll concentrations between pseudopellets and unprocessed sediments (Bartolini et al., 2011). Among sites with Avicennia vegetation cover (AV1, AV2 and AV3), significant differences in SOC were found between different soil depth intervals. This suggests that vegetation is not the only factor influencing the fate of organic matter into the soil. Differences in crab population composition may explain the highest OC concentration (26.93 $\mathrm{mg} \mathrm{g}^{-1}$ ) and stored amount (6.86 $\mathrm{kg} \mathrm{m}^{-2}$ ) in the $20-40 \mathrm{~cm}$ interval in AV3. In AV1 soil, bioturbation by burrowing sesarmids not only allows transport of non-decomposed organic matter, but also of oxygen, to subsurface layers at low tides. Crab channels, by providing a much larger surface area available for gas exchange with the atmosphere, result in oxidized portions (Araújo et al., 2012; Ferreira et al., 2007b; Kristensen et al., 2008, 2011), evidenced by complex redoximorphic pedofeatures. Oxidation of organic matter leads to a decrease of organic carbon content within the soil. In AV2, despite the intense burrowing crab activity, more prolonged waterlogging condition than in AV1 likely prevents SOM oxidation (Marchand et al., 2004), leading to a significantly highest SOC content in the $0-20 \mathrm{~cm}$ soil interval. We can hypothesise that AV1, as representative soil of the margin of the Avicennia belt, evidences a zone that might shift to a more degraded condition due to a progressive depletion of organic matter and nutrients, especially in the upper $40 \mathrm{~cm}$ of soil where live root biomass is significantly concentrated (Komiyama et al., 2000; Tamooh et al., 2008). Conversely, the effect of burrowing crabs on OC storage was suggested by the significantly higher SOC in the deepest soil layer $(40-80 \mathrm{~cm})$, in sites where sesarmids are abundant (AV1-AV2 and RHI), than in those where they are absent (DES1-DES2-AV3 and CER). Moreover, radiocarbon dating revealed that soil organic matter in $\mathrm{Bg} 2$ horizon $(55 / 80-115 \mathrm{~cm}$ depth) in AV1 is modern, $103.0 \pm 0.4$ pMC, confirming that burrowing sesarmids provide a continuous supply of fresh organic matter down the profile. In addition the presence of water with low oxygen saturation, covering the bottom of the sesarmid burrows, avoids oxidation also at low tide. In the other sites, where Uca activity prevails and is localised in the upper part of the profiles with very shallow burrows (Bartolini et al., 2011), characterised by high porewater oxygen content, organic matter in the deep horizons is mainly due to plant material burrowed or deposited in the past. Radiocarbon ages of $3850 \pm 30 \mathrm{yr}$ $\mathrm{BP}$ for the Desert-like belt (DES) and of $2270 \pm 30 \mathrm{yr}$ BP for AV3 soil match those reported by Ramsay and Cooper (2002) for Holocene transgressions to a maximum of $3.5 \mathrm{~m}$ asl. Rapid sea level rises caused accumulation of sulphides in submerged terrestrial surface soils (Dent and Pons, 1995; Van Breemen, 1980). Potential acidity was accumulated as pyrite and was expressed by oxidation during the following regressions (Ramsay and Cooper, 2002). The effects of Holocene fluctuations prevented achievement of any tides-plant-soil equilibrium, leading to the present-day bare belt bordering mangroves landwards. The shallow depth at which such old organic matter was found confirms that the Gazi mangrove is characterised by a low sedimentation rate (Kitheka, 1996), and that carbon burial depends on other processes than sedimentation.

\section{Conclusions}

At least two ecosystem strategies, involving plants, animals and soil, can be delineated with a process-based view of self-organising ecosystems. Scarce resources in the desert-like and Upper eulittoral belts (DES1-DES2-AV3 and CER) impose a tight use of food resources by Uca; low and localised turnover allows OM preservation. At the opposite, burrowing sesarmids, preferentially living under dense vegetation (AV1-AV2-RHI), act as ecosystem engineers; through biogenic structures, they deeply modify soil characters, with favourable effects to soil carbon storage. However, in AV1 it seems that when fast nutrient turnover is not counterbalanced by the preservation of organic matter due to waterlogging, a negative feedback effect is evident. Thus the understanding of key-bioturbating fauna impact on spatial and temporal soil carbon storage and soil heterogeneity may be a research challenge to improve the understanding of the entire mangrove ecosystem functioning and dynamics. 
It can be hypothesised that a set of soil properties may evolve through the response of macrofauna to changes in environmental conditions or nutrient availability. Enlarging this data set of combined field observation of soils, macrobenthos and vegetation may provide the opportunity to identify specific soil architectures associated with mangrove ecosystem functioning.

The importance of mangrove ecosystem as a carbon sink is widely recognised. However, to our knowledge, this work provides the first attempt to assess a linkage between bioturbating crabs and soil carbon storage. Mangrove crabs, being strictly involved in the overall soil carbon sequestration, should be considered as an important component in climate change mitigation strategies and policies.

Supplementary data to this article can be found online at http://dx. doi.org/10.1016/j.seares.2013.08.010.

\section{Acknowledgement}

This study was funded by the EU 6FP PUMPSEA project, contract no. INCO-CT2004-510863, and by the SP3-People (Marie Curie) IRSES Project CREC (no. 247514).

\section{References}

Adams, W.A., 1973. The effect of organic matter on the bulk and true densities of some uncultivated Podzolic soils. Eur. J. Soil Sci. 24, 10-17.

Alongi, D.M., 2002. Present state and future of the world's mangrove forests. Environ. Conserv. $29,331-349$.

Alongi, D.M., 2009. Paradigm shifts in mangrove biology. In: Wolanski, E.J., Perillo, G.M.E., Cahoon, D.R., Brinson, M.M. (Eds.), Coastal Wetlands. An Integrated Ecosystem Approach. Elsevier, pp. 615-640 (974 p.).

Alongi, D.M., Pfitzner, J., Trott, L.A., Tirendi, F., Dixon, P., Klumpp, D.W., 2005. Rapid sediment accumulation and microbial mineralization in forests of the mangrove Kandelia candel in the Jiulongjiang Estuary, China. Estuar. Coast. Shelf Sci. 63, 605-618.

Anderson, M.J., 2001a. A new method for non-parametric multivariate analysis of variance. Aust. Ecol. 26, 32-46.

Anderson, M.J., 2001b. Permutation tests for univariate or multivariate analysis of variance and regression. Can. J. Fish. Aquat. Sci. 58, 629-636.

Anderson, M.J., 2008. In: Gorley, R.N., Clarke, K.R. (Eds.), PERMANOVA for PRIMER: Guide to Software and Statistical Methods. PRIMER-E Ltd., Plymouth, UK.

Andreetta, A., Ciampalini, R., Moretti, P., Vingiani, S., Poggio, G., Matteucci, G., Tescari, F., Carnicelli, S., 2011. Forest humus forms as potential indicators of soil carbon storage in Mediterranean environments. Biol. Fertil. Soils 47, 31-40.

Araújo Jr., J.M.C., Otero, X.L., Marques, A.G.B., Nóbrega, G.N., Silva, J.R.F., Ferreira, T.O., 2012. Selective geochemistry of iron in mangrove soils in a semiarid tropical climate: effects of the burrowing activity of the crabs Ucides cordatus and Uca maracoani. Geo-Mar. Lett. 32, 289-300.

Bartolini, F., Cimò, F., Fusi, M., Dahdouh-Guebas, F., Lopes, G.P., Cannicci, S., 2011. The effect of sewage discharge on the ecosystem engineering activities of two east African fiddler crab species: consequences for mangrove ecosystem functioning. Mar. Environ. Res. 71, 53-61.

Booksmythe, I., Hayes, C., Jennions, M.D., Backwell, P.R.Y., 2012. The effects of neighbor familiarity and size on cooperative defense of fiddler crab territories. Behav. Ecol. 23, 285-289.

Bouillon, S., Dahdouh-Guebas, F., Rao, A.V.V.S., Koedam, N., Dehairs, F., 2003. Sources of organic carbon in mangrove sediments: variability and possible ecological implications. Hydrobiologia 495, 33-39.

Breithaupt, J.L., Smoak, J.M., Smith III, T.J., Sanders, C.J., Hoare, A., 2012. Organic carbon burial rates in mangrove sediments: strengthening the global budget. Glob. Biogeochem. Cycles. http://dx.doi.org/10.1029/2012GB004375.

Cannicci, S., Burrows, D., Fratini, S., Smith III, T.J., Offenberg, J., Dahdouh-Guebas, F., 2008. Faunal impact on vegetation structure and ecosystem function in mangrove forests: a review. Aquat. Bot. 89, 186-200.

Cannicci, S., Bartolini, F., Dahdouh-Guebas, F., Fratini, S., Litulo, C., Macia, A., Mrabu, E.J., Penha-Lopes, G., Paula, J., 2009. Effects of urban wastewater on crab and mollusc assemblages in equatorial and subtropical mangroves of East Africa. Estuar. Coast. Shelf Sci. 84, 305-317.

Chmura, G.L., Anisfeld, S.C., Cahoon, D.R., Lynch, J.C., 2003. Global carbon sequestration in tidal, saline wetland soils. Glob. Biogeochem. Cycles 17 (4), 1111.

Crane, J., 1975. Fiddler Crabs of the World. Princeton University Press, Princeton (NJ).

Dahdouh-Guebas, F., Verneirt, M., Tack, J.F., Koedam, N., 1997. Food preferences of Neosarmatium meinerti de Man (Decapoda: Sesarminae) and its possible effect on the regeneration of mangroves. Hydrobiologia 347, 83-89.

Dahdouh-Guebas, F., Verneirt, M., Cannicci, S., Kairo, J.G., Tack, J.F., Koedam, N., 2002. An exploratory study on grapsid crab zonation in Kenyan mangroves. Wetlands Ecol. Manage. 10, 179-187.

De Vos, B., Van Meirvenne, M., Quataert, P., Deckers, J., Muys, B., 2005. Predictive quality of pedotransfer functions for estimating bulk density of forest soils. Soil Sci. Soc. Am. J. $69,500-510$.
Dent, D., 1986. Acid Sulphate Soils: A Baseline for Research and Development. International Institute for Land Reclamation and Improvement (ILRI Publ.39), Wageningen, Netherlands.

Dent, D.L., Pons, L.J., 1995. A world perspective on acid sulphate soils. Geoderma 67, 263-276.

Derijard, R., 1966. Note préliminaire sur les Crustacés Stomatopodes et Décapodes récoltes a l'ile Europa du 6 au 24 Avril 1964. Mem. Mus. Natn. Hist. Nat. Paris (A) 41, 159-180.

Dittmar, T., Hertkorn, N., Kattner, G., Lara, R.J., 2006. Mangroves, a major source of dissolved organic carbon to the oceans. Glob. Biogeochem. Cycles 20.

Donato, D.C., Kauffman, J.B., Murdiyarso, D., Kurnianto, S., Stidham, M., Kanninen, M. 2011. Mangroves among the most carbon-rich forests in the tropics. Nat. Geosci. 4, 293-297.

Duarte, C.M., Middelburg, J.J., Caraco, N., 2005. Major role of marine vegetation on the oceanic carbon cycle. Biogeosciences 2, 1-8.

Dye, A.H., Lasiak, T.A., 1987. Microbenthos, meiobenthos and fiddler crabs: trophic interactions in a tropical mangrove sediments. Mar. Ecol. Prog. Ser. 32, 259-264.

Edney, E.B., 1961. The water and heat relationships of fiddler crabs (Uca spp.). Trans. R. Soc. S. Africa 36 (2), 71-91.

Emmerson, W.D., McGwynne, L.E., 1992. Feeding and assimilation of mangrove leaves by the crab Sesarma meinerti de Man in relation to leaf-litter production in Mgazana, a warm-temperate southern African mangrove swamp. J. Exp. Mar. Biol. Ecol. 157, 41-53.

Eong, O.J., 1993. Mangroves - a carbon source and sink. Chemosphere 27, 1097-1107.

Ferreira, T.O., Vidal-Torrado, P., Otero, X.L., Macías, F., 2007a. Are mangrove forest substrates sediments or soils? A case study in southeastern Brazil. Catena 70, 79-91.

Ferreira, T.O., Otero, X.L., Vidal-Torrado, P., Macías, F., 2007b. Effects of bioturbation by root and crab activity on iron and sulfur biogeochemistry in mangrove substrate. Geoderma 142, 36-46.

Fratini, S., Cannicci, S., Vannini, M., 2000. Competition and interaction between Neosarmatium smithi (Crustacea: Grapsidae) and Terebralia palustris (Mollusca: Gastropoda) in a Kenyan mangrove. Mar. Biol. 137, 309-316.

Fujimoto, K., Imaya, A., Tabuchi, R., Kuramoto, S., Utsugi, H., Murofushi, T., 1999. Belowground carbon storage of Micronesian mangrove forests. Ecol. Res. 14, 409-413.

Gee, G.W., Bauder, J.W., 1986. Particle-size analysis. In: Klute, A. (Ed.), Methods of Soil Analysis: Part 1. Physical and Mineralogical Methods, 32. Am. Soc. Agr. Soil Sci. Soc. Am, Madison, pp. 383-412.

Geist, S.J., Nordhaus, I., Hinrichs, S., 2012. Occurrence of species-rich crab fauna in a human-impacted mangrove forest questions the application of community analysis as an environmental assessment tool. Estuar. Coast. Shelf Sci. 96, 69-80.

Giri, C., Ochieng, E., Tieszen, L.L., Zhu, Z., Singh, A., Loveland, T., Masek, J., Duke, N., 2011 Status and distribution of mangrove forests of the world using earth observation satellite data. Glob. Ecol. Biogeogr. 20, 154-159.

Hartnoll, R.G., 1975. The Grapsidae and Ocypodae (Decapoda: Brachiyura) of Tanzania J. Zool. 177, 305-328.

Holguin, G., Vazquez, P., Bashan, Y., 2001. The role of sediment microorganisms in the productivity, conservation, and rehabilitation of mangrove ecosystems: an overview. Biol. Fertil. Soils 33, 265-278.

Hartnoll, R.G., Cannicci, S., Emmerson, W.D., Fratini, S., Macia, A., Mgaya, Y., Porri, F., Ruwa, R.K., Shunula, J.P., Skov, M.W., 2002. Geographic trends in mangrove crab abundance in East Africa. Wetlands Ecol. Manag. 10, 203-213.

Howe, A.J., Rodríguez, J.F., Saco, P.M., 2010. Surface evolution and carbon sequestration in disturbed and undisturbed wetland soils of the Hunter estuary, southeast Australia. Estuar. Coast. Shelf Sci. 84, 75-83.

Icely, J.D., Jones, D.A., 1978. Factors affecting the distribution of the genus Uca (Crustacea: Ocypodidae) on an East African shore. Estuar. Coast. Shelf Sci. 6 , 315-322.

IUSS Working Group WRB, 2006. World reference base for soil resources 2006. World Soil Resources Reports No. 103. FAO, Rome.

Jobbágy, E.G., Jackson, R.B., 2000. The vertical distribution of soil organic carbon and its relation to climate and vegetation. Ecol. Appl. 10, 423-436.

Joffe, J.S., 1936. Pedology. Rutgers University Press, New Brunswick, NJ.

Jones, D.A., 1984. Crabs of the mangal ecosystem. In: Por, F.D., Junk, I.D. (Eds.), Hydrobiology of the Mangal, pp. 89-109.

Kauffman, J.B., Heider, C., Cole, T.G., Dwire, K.A., Donato, D.C., 2011. Ecosystem carbon stocks of Micronesian mangrove forests. Wetlands 31, 343-352.

Kaur, R., Kumar, S., Gurung, H.P., 2002. A pedo-transfer function (PTF) for estimating soil bulk density from basic soil data and its comparison with existing PTFs. Aust. J. Soil Res. 40, 847-857.

Kitheka, J.U., 1996. Water circulation and coastal trapping of brackish water in a tropical mangrove-dominated bay in Kenya. Limnol. Oceanogr. 41, 169-176.

Koch, V., Wolff, M., 2002. Energy budget and ecological role of mangrove epibenthos in the Caeté estuary, North Brazil. Mar. Ecol. Prog. Ser. 228, 119-130.

Komiyama, A., Havanond, S., Srisawatt, W., Mochida, Y., Fujimoto, K., Ohnishi, T., Ishihara, S., Miyagi, T., 2000. Top/root biomass ratio of a secondary mangrove (Ceriops tagal (Perr.) C.B. Rob.) forest. For. Ecol. Manag. 139, 127-134.

Kristensen, E., Alongi, D.M., 2006. Control by fiddler crabs (Uca vocans) and plant roots (Avicennia marina) on carbon, iron, and sulfur biogeochemistry in mangrove sediment. Limnol. Oceanogr. 51, 1557-1571.

Kristensen, E., Bouillon, S., Dittmar, T., Marchand, C., 2008. Organic carbon dynamics in mangrove ecosystems: a review. Aquat. Bot. 89, 201-219.

Kristensen, E., Mangion, P., Tang, M., Flindt, M.R., Holmer, M., Ulomi, S., 2011. Microbial carbon oxidation rates and pathways in sediments of two Tanzanian mangrove forests. Biogeochemistry 103, 143-158.

Lee, S.Y., 1998. Ecological role of grapsid crabs in mangrove ecosystems: a review. Mar. Freshw. Res. 49, 335-343. 
Lee, S.Y., 2008. Mangrove macrobenthos: assemblages, services, and linkages. J. Sea Res. $59,16-29$.

Macintosh, D.J., 1977. Quantitative sampling and production estimates of fiddler crabs in a Malaysian mangrove. Mar. Res. Indones. 18, 59.

Macintosh, D.J., De Silva, S.S., 1984. The influence of stocking density and food ration on fry survival and growth in Oreochromis mossambicus and 0 . niloticus female $\times 0$. aureus male hybrids reared in a closed circulated system. Aquaculture 41, 345-358.

Macnae, W., 1968. A general account of the flora and fauna of the mangrove swamps and forests in the Indo-Pacific Region. Adv. Mar. Biol. 6, 73-270.

Macnae, W., Kalk, M., 1962. The ecology of mangrove swamps at Inhaca Island Mozambique J. Ecol. 50, 19-34.

Manrique, L.A., Jones, C.A., 1991. Bulk density of soils in relation to soil physical and chemical properties. Soil Sci. Soc. Am. J. 55, 476-481.

Marchand, C., Baltzer, F., Lallier-Vergès, E., Albéric, P., 2004. Pore-water chemistry in mangrove sediments: relationship with species composition and developmental stages (French Guiana). Mar. Geol. 208, 361-381.

Matsui, N., 1998. Estimated stocks of organic carbon in Mangrove roots and sediments in Hinchinbrook Channel. Aust. Mangroves Salt Marshes 2, 199-204.

Matthijs, S., Tack, J., van Speybroeck, D., Koedam, N., 1999. Mangrove species zonation and soil redox state, sulphide concentration and salinity in Gazi bay (Kenya), a preliminary study. Mangroves Salt Marshes 3, 243-249.

Mautz, B., Detto, T., Wong, B.B.M., Kokko, H., Jennions, M.D., Backwell, P.R.Y., 2011. Male fiddler crabs defend multiple burrows to attract additional females. Behav. Ecol. 22 261-267.

Micheli, F., 1993. Feeding ecology of mangrove crabs in north eastern Australia: mangrove litter consumption by Sesarma messa and Sesarma smithii. J. Exp. Mar. Biol. Ecol. 171, 165-186.

Micheli, F., Gherardi, F., Vannini, M., 1991. Feeding and burrowing ecology of two East African mangrove crabs. Mar. Biol. 111, 247-254.

Middelburg, J.J., Nieuwenhuize, J., Slim, F.J., Ohowa, B., 1996. Sediment biogeochemistry in an East African mangrove forest (Gazi Bay, Kenya). Biogeochemistry 34, 133-155.

Milner, R., Booksmythe, I., Jennions, M.D., Backwell, P.R.Y., 2010. The battle of the sexes? Territory acquisition and defence in male and female fiddler crabs. Anim. Behav. 79, 735-738.

Nagelkerken, I., Blaber, S.J.M., Bouillon, S., Green, P., Haywood, M., Kirton, L.G., Meynecken, J.O., Pawlik, J., Penrose, H.M., Sasekumar, A., Somerfield, P.J., 2008. The habitat function of mangroves for terrestrial and marine fauna: a review. Aquat. Bot. 89, 155-185.

Nordhaus, I., Hadipudjana, F.A., Janssen, R., Pamungkas, J., 2009. Spatio-temporal variation of macrobenthic communities in the mangrove-fringed Segara Anakan lagoon, Indonesia, affected by anthropogenic activities. Reg. Environ. Change 9, 291-313.

Page, S.E., Rieley, J.O., Banks, C.J., 2011. Global and regional importance of the tropical peatland carbon pool. Glob. Change Biol. 17, 798-818.

Paton, T.R., Humphreys, G.S., Mitchell, P.B., 1995. Soils. A New Global View. UCL Press, London.

Penha-Lopes, G., Bartolini, F., Limbu, S., Cannicci, S., Kristensen, E., Paula, J., 2009. Are fiddler crabs potentially useful ecosystem engineers in mangrove wastewater wetlands? Mar. Pollut. Bull. 58, 1694-1703.

Ragionieri, L., Fratini, S., Schubart, C.D., 2012. Revision of the Neosarmatium meinerti species complex (Decapoda: Brachyura: Sesarmidae), with descriptions of three pseudocryptic indo-west pacific species. Raffles Bull. Zool. 60, 71-87.

Ramsay, P.J., Cooper, J.A.G., 2002. Late quaternary sea-level change in South Africa. Quat. Res. 57, 82-90.

Ranjan, R.K., Routh, J., Ramanathan, A.L., Klump, J.V., 2011. Elemental and stable isotope records of organic matter input and its fate in the Pichavaram mangrove-estuarine sediments (Tamil Nadu, India). Mar. Chem. 126, 163-172.
Reinsel, K.A., 2004. Impact of fiddler crab foraging and tidal inundation on an intertidal sandflat: season-dependent effects in one tidal cycle. J. Exp. Mar. Biol. Ecol. 313, 1-17.

Ribeiro, P.D., Iribarne, O.O., 2011. Coupling between microphytobenthic biomass and fiddler crab feeding. J. Exp. Mar. Biol. Ecol. 407, 147-154

Robert, E., Schmitz, N., Ali Kirauni, H., Koedam, N., 2009. Salinity fluctuations in mangrove forest of Gazi bay, Kenya: lessons for future research. Nat. Faune 24, 89-95.

Robertson, A.I., 1986. Leaf-burying crabs: their influence on energy flow and export from mixed mangrove forests (Rhizophora spp.) in northeastern Australia. J. Exp. Mar. Biol. Ecol. 102, 237-248

Robertson, A.I., 1991. Plant-animal interactions and the structure and function of mangrove forest ecosystem. Aust. J. Ecol. 16, 433-443.

Robertson, A.I., Daniel, P.A., 1989. The influence of crabs on litter processing in high intertidal mangrove forests in tropical Australia. Oecologica 78, 191-198.

Sanders, C.J., Smoak, J.M., Naidu, A.S., Sanders, L.M., Patchineelam, S.R., 2010a. Organic carbon burial in a mangrove forest, margin and intertidal mud flat. Estuar. Coast. Shelf Sci. 90, 168-172.

Sanders, C.J., Smoak, J.M., Sanders, L.M., Naidu, A.S., Patchineelam, S.R., 2010b. Organic carbon accumulation in Brazilian mangal sediments. J. South Amer. Earth Sci. 30, 189-192.

Schmitz, N., Robert, E.M.R., Verheyden, A., Kairo, J.G., Beeckman, H., Koedam, N., 2008. A patchy growth via successive and simultaneous cambia: key to success of the most widespread mangrove species Avicennia marina? Ann. Bot. 101, 49-58.

Skov, M.W., Hartnoll, R.G., 2001. Comparative suitability of binocular observation, burrow counting and excavation for the quantification of the mangrove fiddler crab Uca annulipes (H. Milne Edwards). Hydrobiologia 449, 201-212.

Skov, M.W., Hartnoll, R.G., 2002. Paradoxical selective feeding on a low-nutrient diet: why do mangrove crabs eat leaves? Oecologica 131, 1-7.

Smith III, T.J., Boto, K.G., Frusher, S.D., Giddins, R.L., 1991. Keystone species and mangrove forest dynamics: the influence of burrowing by crabs on soil nutrient status and forest productivity. Estuar. Coast. Shelf Sci. 33, 419-432.

Soil Survey Staff, 2010. Keys to Soil Taxonomy, 11th ed. USDA - Natural Research Conservation Services, Washington, DC.

Sousa, W.P., Dangremond, E.M., 2011. Trophic interactions in coastal and estuarine mangrove forest ecosystems. In: Wolanski, E., McLusky, D.S. (Eds.), Treatise on Estuarine and Coastal Science, vol. 6. Academic Press, Waltham, pp. 43-93.

Tamooh, F., Huxham, M., Karachi, M., Mencuccini, M., Kairo, J.G., Kirui, B., 2008. Belowground root yield and distribution in natural and replanted mangrove forests at Gazi Bay, Kenya. For. Ecol. Manag. 256, 1290-1297.

Thongtham, N., Kristensen, E., 2005. Carbon and nitrogen balance of leaf-eating sesarmid crabs (Neoepisesarma versicolor) offered different food sources. Estuar. Coast. Shelf Sci. 65, 213-222.

Tue, N.T., Hamaoka, H., Sogabe, A. Ouy, T.D., Nhuan, M.T., Omori, K., 2011. The application of $\delta^{13} \mathrm{C}$ and $\mathrm{C} / \mathrm{N}$ ratios as indicators of organic carbon sources and paleoenvironmental change of the mangrove ecosystem from Ba Lat Estuary, Red River, Vietnam. Environ. Earth Sci. 64, 1475-1486.

Twilley, R.R., Pozo, M., Garcia, V.H., Rivera-Monroy, V.H., Zambrano, R., Bodero, A., 1997. Litter dynamics in riverine mangrove forests in the Guayas River estuary, Ecuador. Oecologica 111, 109-122.

Van Breemen, N., 1980. Acid sulphate soils. Land reclamation and water management. ILRI Publ. 27. Wageningen, pp. 53-57.

Wells, F.E., 1984. Comparative distribution of macromolluscs and macrocrustaceans in a north-western Australian mangrove system. Aust. J. Mar. Freshw. Res. 35, 591-596.

Zeil, J., Hemmi, J.M., Backwell, P.R.Y., 2006. Fiddler crabs. Curr. Biol. 16, 40-41. 